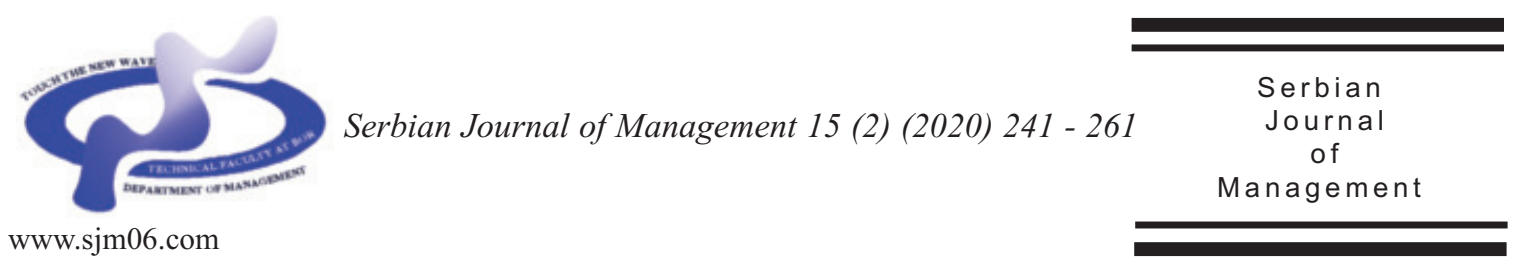

\title{
APPLICATION OF MODIFIED GARCH METHODOLOGY: DEVELOPED FINANCIAL MARKETS VERSUS EMERGING FINANCIAL MARKETS
}

\author{
Nenad Penezića ${ }^{a}$, Goran Anđelića ${ }^{a}$, Marko R Miloševića ${ }^{a^{*}}$ and Vilmoš Tot ${ }^{b}$

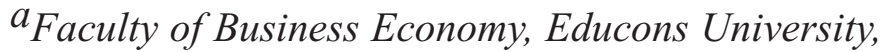 \\ Vojvode Putnika BB, 21208, Sremska Kamenica, Serbia

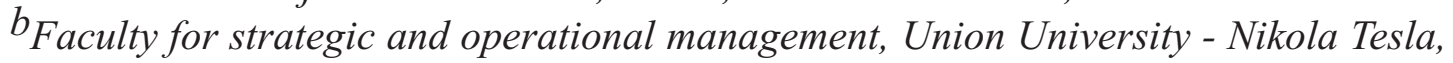 \\ Cara Dušana 62-64, Belgrade, Serbia
}

(Received 30 December 2018; accepted 24 January 2019)

\begin{abstract}
The subject of this research is to analyze and test the modified GARCH methodology in terms of quantifying the impact of inflation rates, interest rates on government bonds, reference interest rates, and exchange rates on daily rates of return on investment activities in the observed financial markets of North America, Serbia and Croatia. The aim of the research, i.e. a special focus in the research, is to compare the obtained results between the developed financial markets and the financial markets of developing countries, as well as to test the modified GARCH methodology in the observed financial markets. The key indicators in the research, presumed to affect the daily return rates, were the following: inflation rate, interest rates on government bonds, reference interest rate and exchange rate. The time period covered by the research is from 2005 to 2017, where the width of the research time horizon allows testing the modified GARCH methodology in the periods before, during and after the global financial crisis. In addition to the use of modified GARCH econometric models, the research methodology includes the use of AIC, SIC and HQC (Akaike, Schwarz and Hannan-Quinn) criteria for selecting the best models, as well as the appropriate tests that are suitable for and/or adapted to the specific characteristics of financial markets of both developed and developing countries. The research results confirm the role and importance of the modified GARCH methodology for effective investment risk quantification in developed financial markets versus the financial markets of developing countries. In this sense, the obtained research results will be useful to both the academic community and the professional public in the context of investment decision making.
\end{abstract}

Keywords: GARCH, risk, developed financial markets, emerging markets

\footnotetext{
*Corresponding author: milosevicm1@gmail.com
}

DOI: $10.5937 /$ sjm15-20566 


\section{INTRODUCTION}

Current circumstances in the financial markets, globalization trends, the financial crisis and significant volatility of the market are some of the key conditions that have influenced the change in the logic of financial thinking. The forecasting methods and techniques of the expected corresponding investment effects have been inevitably changed and adapted to contemporary market conditions and opportunities. Investing in financial markets today must be considered differently and analyzed in relation to the period before the outbreak of the financial crisis. Therefore, it must be seen in the context of modern market conditions, with a resulting change of the investment strategy in order to optimise the effects. As the functionality and symmetry of the daily return rates on financial markets have a different "form" after the financial crisis, researchers must use custom models to analyze and quantify the risks of investment activities.

Compared with developed financial markets, emerging markets are rather volatile, underdeveloped and "shallow," characterised by the lack of continuous trading, low liquidity, low capitalization, lack of high turnover, and low efficiency. However, the benefits of the financial markets of developing countries are reflected in the fact that they bear a higher risk, as well as higher returns on investment activities.

Practical testing of econometric models provides information on their quality and efficiency in order to define and measure investment return volatility. In addition, the basic and modified econometric models should be continually tested, emphasising investment risk minimisation, especially given their specificities. As a quantified measure of market risk, volatility estimation is of great importance for investment decisions, where return volatility estimation represents the most important input for determining the optimal investment strategy.

The research subject is the analysis and testing of the modified GARCH methodology in terms of quantification of the inflation rate, the interest rate on government bonds, the reference interest rates and the exchange rate on the daily return rates on investment activities in the observed financial markets of North America, Serbia and Croatia. The period covered by the research is from 2005 to 2017. The width of the research time horizon allows testing the success of the modified GARCH methodology in the periods before, during and after the global financial crisis.

The aim of the research is to compare the obtained results between the developed and emerging financial markets, as well as to test the modified GARCH methodology in the observed financial markets. The key indicators presumed to affect the daily return rates are the following: the inflation rate, the interest rates on government bonds, the reference interest rate and the exchange rate. The specific research objectives are focused on testing the modified GARCH methodology in the pre-crisis, crisis and post-crisis periods.

The specificity of the financial markets of developing countries including the markets of the Republic of Serbia and Croatia is the fact that investing in these markets means both high return and high risk, unlike in developed financial markets. However, if compared with the developed financial markets, the financial markets of developing countries provoke financial-econometric practice to test the performance of a modified GARCH methodology in order to 
optimize investment strategies.

Testing and contrasting the modified GARCH methodology on both developed and emerging markets not only provide quantitative information on the impact effectiveness but also analyse the differences between the observed financial markets in the pre-crisis, crisis and post-crisis periods. The following hypotheses have been tested in this study:

HO: The application of the modified GARCH methodology in order to quantify the impact of the inflation rate, the interest rates on government bonds, the reference interest rates and the exchange rate on the daily rates of return significantly contributes to reducing the risk of investment activities.

Accordingly, the additional (derived) hypotheses have been tested as follows:

H1: The application of the modified GARCH 1.1 model can be equally successful in both developed and emerging markets.

H2: The modified GARCH 1.1 model is the most effective for assessing the impact significance of some particular macroeconomic factors.

The paper is structured in the following way: the subject of the research, the goal, and the hypotheses are defined in the introductory considerations. The next part of the paper presents relevant research literature. The third part deals with the methodology and sample used in the research. The results and discussion are presented in the next section, followed by the conclusions and references used in the paper.

\section{LITERATURE REVIEW}

Using the asymmetric GJR-GARCH model, the study by Cakan et al. (2015) analyses the impact of US macroeconomic news on the volatility of the daily return rates of the twelve emerging markets. The applied asymmetric model includes both positive and negative news, i.e. announcements in the US about the inflation rate and unemployment. The authors conclude that asymmetric volatility grows with bad news about macroeconomic impacts in the US in comparison to developing financial markets, where 5 out of 12 respond to negative announcements of the inflation rate, while 4 out of 12 respond to negative announcements about unemployment. Asymmetric volatility declines with good macroeconomic indicators in the US in 8 out of 12 countries. The financial markets of developing countries are becoming less risky for investors and less volatile with good macroeconomic indicators in the US.

Li, Zhong and Huang (2020), explored the the dependence of financial cycles in emerging and developed countries from January 1993. to December 2017. by applying an ARIMA $(2,1,2)-G A R C H(1,1)$ model and capture the dependence structures by selecting the optimal copula model. The authors concluded that the financial cycle has obvious characteristics that can be roughly divided into three stages and emerging countries show more interdependence and a higher degree of dependence than developed countries.

The relationship between the volatility of stock market returns and macroeconomic volatilities has been a focus of many studies, but these studies are mostly based on data from developed financial markets, while just a few have been done on the basis of data from the financial markets of developing countries. In the study by Zukarnain and Sofian (2012), the GARCH 1.1 model was used to estimate the volatility of daily returns and the impact of five macroeconomic 
factors in Malaysia: GDP, inflation rate, exchange rate, interest rates and money supply. The authors concluded that there was a very weak relationship between the volatility of the stock market and the macroeconomic volatilities. Only volatility in inflation was found to cause stock market volatility, while out of five macroeconomic variables, only the volatility in interest rates was caused by the volatility of the stock market. All the volatilities of the macroeconomic variables (as a set of variables) also did not cause the volatility in stock market returns. The result from regression analysis using GARCH showed that only money supply volatility was significantly related to stock market volatility. The weak relationship between the stock market volatility and macroeconomic volatilities in the financial markets of developing countries might be due to the lack of institutional investors in the market, and might indicate the existence of information asymmetry problem among investors, the authors concluded.

The research by Shaikh and Padhi (2013), explored the behaviour of the Indian Stock Exchange Index VIX before and after the scheduled release of macroeconomic indicators using GARCH methodology. The study took into account various macroeconomic indicators such as gross domestic product, the employment rate, index of industrial production, the inflation rate, federal monetary policy statement, corporate trust, balance of payments and international reserves levels. The research results showed that the Indian Stock Exchange Index VIX "reacted" significantly to macroeconomic indicators. The employment rate and GDP were found to be statistically significant. It can also be seen that Indian VIX significantly increased before the scheduled release of macroeconomic indicators. FED monetary policy also played a major role in determining portfolio selection. Empirical results showed that market participants considered the Indian Stock Exchange Index VIX as an indicator of future volatility. In addition, the joint effect of more than one macroeconomic announcement on the Stock Exchange Index VIKS was also significant.

In the research by Rejeb and Arfaoui (2016), the degree and structure of interdependence between emerging (Asian and Latin American) and developed (the USA and Japan) stock markets were examined through the study of volatility spillovers in the period 1993-2010. Using both standard GARCH model and quantile regression approach, they found the evidence of significant interdependence between financial markets which might give evidence of volatility transmission. It was closely conditioned by the geographical distance of the financial markets and the global financial and economic crisis; the obtained results validated the large shocks transmission during different crisis periods, which confirmed the presence of "contagion" between developed and emerging financial markets.

The research by Prasad, Grant and Kim (2018) investigates spillovers across 16 major stock markets utilizing the high frequency data based Realized volatility estimator and the spillover index methodology. They find that spillovers increased dramatically during the 2008 global financial crisis and the European sovereign debt crisis that followed as expected. Differences arise when comparing directional spillovers for individual stock markets. They also find that the larger stock markets from the advanced western 
economies, particularly the US, dominate volatility transmission to other markets. Emerging markets such as China, India and Brazil are still relatively isolated, though their contributions to global volatility spillovers have increased considerably after 2006.

Ali and Afzal (2012) explored the impact of the global economic crisis and its spillover to the stocks markets of India (Stock Exchange Index BSE-100) and Pakistan (Stock Exchange Index KSE-100) in the period 2003-2010 using econometric model EGARCH. The research results empirically confirmed that negative events have a more pronounced impact on the stock volatility than positive shocks. The stock markets of India and Pakistan also faced constant "volatility clusters". The results showed that the global economic crisis made a slightly negative impact on stock returns and enhanced volatility in Pakistani and Indian stock exchanges but this impact is stronger on Indian stock market.

The research by Caporale et al. (2016) analysed the effects of newspaper coverage of macro news on stock returns in eight countries belonging to the euro area (Belgium, France, Germany, Greece, Ireland, Italy, Portugal and Spain) using daily data for the period 1994-2013. The econometric analysis was based on the estimation of a VAR-GARCH model. The results showed that positive (negative) releases of macroeconomic indicators had significant positive (negative) effects on stock returns in all cases. The volatility of macroeconomic factors had a significant impact on both stock returns and volatility; in particular, an increase in the volatility of macroeconomic indicators was always associated with a decrease in stock returns. The observed financial markets were particularly responsive to negative announcements of macroeconomic indicators, and the response was larger during the recent crisis period.

Dedi and Yavas (2016) investigated the linkages among equity market returns and volatility spillovers in the financial markets of Germany, Great Britain, China, Russia and Turkey applying GARCH methodology (MARMA, GARCH, GARCH and EGARCH) in the period 2011- 2016. The results of the analysis showed the existence of significant co-movements of returns among the countries in the sample. In addition, the highest volatilities were exhibited by Russia and Turkey, while on the other hand, the UK and the Chinese markets recorded the lowest volatilities.

Andreou et al. (2013) investigated bidirectional linkages between the stock and foreign exchange markets of a number of emerging economies. Using a variant VARGARCH data model at a quarterly level for twelve emerging economies, they found significant significant bidirectional spillovers between stock and foreign exchange markets. They also investigated the effects of a country's choice of exchange rate regime, on the one hand, and the Asian financial crisis, on the other, on the volatility spillover mechanism.

The study by Geetha et al. (2011) was aimed at finding the relationship between inflation and stock returns, while anticipating expected and unexpected inflation. The results showed that there was a long-term relationship between expected and unexpected inflation with stock returns, but there was no short-term relationship between these variables for Malaysia and the US, while the same existed for China.

Applying the GARCH methodology and the Granger causality test, the study by Duppati et al. (2017) examined how and to 
what extent the trading and repayments of US deposit certificates (purchased by China) traded on the New York Stock Exchange contributed to the information flow and prices of financial instruments on the Shanghai Stock Exchange. The results of the survey undoubtedly showed that there was a two-way transmission of feedback between the Chinese and US markets. The effects from NYSE to SSE were larger than the other way round. The results also showed that the spillover effects were higher on the New York Stock Exchange.

Kim and Won (2018) propose a new hybrid long short-term memory (LSTM) model to forecast stock price volatility that combines the LSTM model with various generalized autoregressive conditional heteroscedasticity (GARCH)-type models. They compare their performance with existing methodologies by analyzing single models, such as the GARCH, exponential GARCH, exponentially weighted moving average, a deep feedforward neural network (DFN), and the LSTM, as well as the hybrid DFN models combining a DFN with one GARCH-type model. The research result discover that GEW-LSTM, a proposed hybrid model combining the LSTM model with three GARCH-type models, has the lowest prediction errors in terms of mean absolute error (MAE), mean squared error (MSE), heteroscedasticity adjusted MAE (HMAE), and heteroscedasticity adjusted MSE (HMSE). They concluded that the the proposed methodology can be extended to various fields as an integrated model combining time-series and neural network models as well as forecasting stock market volatility.

Taking into account the dynamic conditions in the financial markets, it is evident that the frequency of volatile market movements significantly influences the flow and effects of daily returns on investment activities. Due to the outbreak of the global economic crisis, as well as the redefinition of market relations and business conditions, the presentation of different risk management models of investment activities is in the focus of many researchers.

\section{METHODOLOGY}

The research sample includes daily values and calculated return rates for the following stock indices: CROBEX (the representative indicator of the Croatian stock market), BELEX15 (the representative indicator of the stock market of Serbia) and DJIA (the representative indicator of the stock exchange market of North America). The research timeline covers the period from January 1, 2005, to December 31, 2017. The width of the time horizon allows testing of the model effects in the period before, during and after the global economic and financial crisis. According to Brooks (2008), the rate of return is calculated according to the formula:

$$
Y_{t}=\left(\ln P_{t} / P_{t-1}\right) \cdot 100
$$

where $Y_{t}$ is the logarithmic return rate of the stock exchange index at the time $t$, while $P_{t}$ and $P_{t-1}$ represent the empirical values of the observed series in the period $t$ and in the previous period, i.e. in the period of the first delay, respectively.

The authors used an appropriate methodology for volatility modelling and research hypotheses testing. They used GARCH (Generalized Autoregressive Conditional Heteroskedasticity) models to confirm the hypotheses in work. The most 
adequate model was selected for each country and for each observation period, in order to show the significance of the impact of macroeconomic factors.

All the models in the paper were calculated using the EViews software package, using the Marquardt optimization algorithm and the Bollerslev-Wooldridge method (1992) for correcting standard error estimates. The parameters of the used custom GARCH models were estimated using the maximum credibility method. The maximum credibility method allows obtaining grades that are asymptotically more effective than estimates that can be obtained using other methods.

The GARCH (1.1) model for the time series (Brooks, 2008) that is used further in the paper is presented as follows:

$$
\begin{aligned}
& Y_{t}=c+X^{\prime}{ }_{t} \theta+\varepsilon_{t} \\
& \varepsilon_{t}=\sqrt{h_{t} \eta_{t}}, \eta_{t} \stackrel{I I D}{\rightarrow}_{N}(0,1) \\
& h_{t}=a_{0}+\sum_{i=1}^{q} a_{i} \varepsilon^{2}{ }_{t-i}+\sum_{j=1}^{p} b_{j} h_{t-j} \\
& h^{2}{ }_{t}=c+\alpha \varepsilon^{2}{ }_{t-1}+\beta h^{2}{ }_{t-1}
\end{aligned}
$$

where $h_{t}$ is a conditional variance or deviation from $\varepsilon_{t}$ according to the information available at the time $t$, while $c$ represents a constant and $X_{t}^{\prime} \theta$ represents an exogenous variable included in the central equation. $\varepsilon 2_{t-i}$ is a component of the ARCH model and presents volatility information in the previous period, which is calculated as the lag of squared residuals from the mean equation; $h_{t-1}$ is a member of the GARCH model and represents a forecast variance for the last period. The parameter $\alpha$ represents the "GARCH" effect. The parameter $\beta$ measures the persistence of conditional volatility regardless of what is happening on the market. The GARCH $(1,1)$ model connects the conditional variance $h_{t}$ with the past function of square errors and past conditional variances. Macroeconomic factors such as inflation rates, reference interest rates, interest rates on government bonds and foreign exchange rates are introduced into basic GARCH models to measure their impact on daily rates of return, thus representing the following GARCH model as:

$$
h^{2}{ }_{t}=c+\sum_{i=1}^{p} \alpha_{i} \varepsilon^{2}{ }_{t-i}+\sum_{j=1}^{q} \beta_{j} h^{2}{ }_{t-j}+Z^{\prime}{ }_{t}
$$

where $Z_{t}^{\prime}$ represents exogenous variables inserted into the model (inflation rate, reference interest rate, interest rate on government bonds and foreign exchange rate).

In order to select the most optimal GARCH model, the types of GARCH models will be presented as follows:

- EGARCH model defined in the following form:

$$
\log \left(h_{t}\right)=a_{0}+\sum_{i=1}^{q} a_{i} g\left(\eta_{t-1}\right)+\sum_{i=1}^{p} b_{i} \log \left(h_{t-i}\right)(7)
$$

where $\varepsilon_{t}=\sqrt{ } h_{t} \eta_{t}$ and $\mathbf{g}\left(\boldsymbol{\eta}_{\mathbf{t}}\right)=\boldsymbol{\theta} \boldsymbol{\eta}_{\mathbf{t}}+\boldsymbol{\gamma}\left[\left|\boldsymbol{\eta}_{\mathbf{t}}\right|-\right.$ $\mathbf{E}\left|\boldsymbol{\eta}_{\mathbf{t}}\right| \mathbf{l}$ represent pondered values of the model innovation with the asymmetric effect between positive and negative returns of financial assets, while $\theta$ and $\gamma$ are constant. Macroeconomic factors such as inflation rates, reference interest rates, interest rates on government bonds and foreign exchange rates are included in the basic EGARCH model to estimate the impact on daily return rates so that the EGARCH model can now be presented in the following way: 


$$
\begin{aligned}
& \log \left(h_{t}{ }^{2}\right)=c+\sum_{j=1}^{q} \beta_{j} \log \left(h^{2}{ }_{t-j}\right)+ \\
& +\sum_{i=1}^{p} \alpha_{i}\left|\frac{\varepsilon_{t-i}}{h_{t-i}}\right|+\sum_{k=1}^{r} \gamma_{k} \frac{\varepsilon_{t-k}}{h_{t-k}}+Z^{\prime}{ }_{t}
\end{aligned}
$$

where the asymmetric effect on conditional volatility is measured by the expression $\alpha\left(\varepsilon_{t-1}\right)$. The asymmetric effect measures the effect size and the sign. The parameter is set to measure the sign. The EGARCH process is covariance stationary if and only if $\beta<1$. $\mathrm{c}$ is a constant (long-term mean). The parameter $\alpha$ represents the "GARCH" effect. The parameter $\beta$ measures the persistence of conditional volatility regardless of what is happening on the market. The parameter $\gamma$ measures the asymmetry or leverage effect, so the EGARCH model allows asymmetry testing. When $\gamma=0$, the model is symmetric, i.e. positive and negative shocks equally affect the volatility of the return series. If $\gamma<0$, positive (good) news from the market generate less volatility than negative shocks. If $\gamma>0$, positive shocks have a greater impact than negative impacts. On the left side of the equation, log is the mark for the conditional variance logarithm. This means that there is an exponential leverage effect in the equation, which guarantees that the conditional variance estimation will be nonnegative. The existence of a leverage effect is tested using the hypothesis that $\gamma_{i}<0$. The asymmetric effect exists if $\gamma_{i} \neq 0$. There are several differences between the EGARCH model specification in Eviews and Nelson's original model.

- TARCH model is presented in the following form:

$$
h_{t}{ }^{2}=w+\sum_{i=1}^{p} \alpha_{i} \varepsilon_{t}^{2}+\sum_{j=1}^{q} \beta_{j} h_{t-j}^{2}+\sum_{i=1}^{p} \gamma_{i} I_{t-i} \varepsilon_{t-i}^{2}
$$

where the function indicator is $I_{t-i}$, while $\alpha$

$$
\text { where } I_{t-i}=\left\{\begin{array}{l}
1 \text { if } \varepsilon_{t-i}<0 \\
0 \text { if } \varepsilon_{t-i} \geq 0
\end{array}\right.
$$

and $\beta$ represent non-negative parameters that satisfy the condition $\alpha+\beta<1$. In addition, in the TARCH model, conditional volatility $h_{t}^{2}$ is positive if $\alpha+\gamma \geq 1$, while the process is stationary in a covariance stationary if and only if $(\alpha+\gamma / 2)+\beta<1$. The parameter $\gamma$ measures the asymmetric or leverage effect in the sense that the artificial variable takes the value of 1 if the residuals are negative, i.e. the value is 0 if the residuals are nonnegative.

The basic version of the TARCH model includes macroeconomic factors to measure the impact on daily rates of return so that the TARCH model can now be presented as follows:

$$
\begin{array}{r}
h^{2}{ }_{t}=c+\sum_{i=1}^{p} \alpha_{i} \varepsilon^{2}{ }_{t-i}+\sum_{j=1}^{q} \beta_{j} h^{2}{ }_{t-j}+ \\
+\sum_{k=1}^{r} \varepsilon^{2}{ }_{t-k} I_{t-k}+Z^{\prime}{ }_{t}
\end{array}
$$

the research, the choice of model adequacy was based on the AIC (Akaike Information Criterion), the SIC (Schwarz Information Criterion) and the HQC

(Hannan-Quinn Criterion), that were used to select the most optimal models and confirm the research hypotheses. According to Gujarati (2010), the used criteria are calculated as follows:

$$
\begin{aligned}
& A I C=\mathrm{l}_{\mathrm{n}}\left(\widehat{\sigma}^{2}\right)+\frac{2 \mathrm{k}}{\mathrm{T}} \\
& S I C=\mathrm{l}_{\mathrm{n}}\left(\widehat{\sigma}^{2}\right)+\frac{\mathrm{k}}{\mathrm{T}} \mathrm{l}_{\mathrm{n}} \mathrm{T} \\
& H Q C=\mathrm{l}_{\mathrm{n}}\left(\widehat{\sigma}^{2}\right)+\frac{2 \mathrm{k}}{\mathrm{T}} \mathrm{l}_{\mathrm{n}}\left(\mathrm{l}_{\mathrm{n}}(\mathrm{T})\right)
\end{aligned}
$$


where $\sigma^{\wedge}$ is a residual variance, which is equivalent to the residual sum of the squares divided by the number of observations in the series, $\mathrm{k}=\mathrm{p}+\mathrm{q}+1$ is the total number of estimated parameters, and $\mathrm{T}$ is the sample size. The strictest penalties were imposed by SIC criterion, AIC has the smallest penalties, while HQC is somewhere in between. Although according to Brooks (2008), the best criterion cannot be claimed, the most optimal models were selected according to the lowest SIC information criterion.

In order to quantify the impact of macroeconomic factors on daily return rates of stock exchange indices, the modified GARCH 1.1, TARCH and EGARCH models were used to assess the impact on all observed financial markets and in all observed periods (the entire period, precrisis, crisis and post-crisis periods). Furthermore, on the basis of the used AIC, SIC and HQC information criteria, the optimal modified GARCH model was selected for all observed periods and especially for each observed market (North America, Croatia and Serbia). Finally, the comparison results of the optimal GARCH modified models will be presented in order to quantify the impact of macroeconomic factors and hypotheses testing.

\section{RESULTS AND DISCUSSION}

In this section of the paper, we will present the results of the modified GARCH models, and analyse and quantify the impact of macroeconomic factors from the aspect of investment activities on the developed versus the emerging financial markets. For each observed financial market, the best modified GARCH model has been selected for the observation period (the entire period, precrisis, crisis and post-crisis periods). Afterwards, the residual motion is graphically presented.

In the following section, the case study of the developed financial market of North America will be presented, through the stock index Dow Jones Industrial Average (DJIA). Table 1 shows used representative AIC, SIC and HQC information criteria, where it will be selected the optimal modified GARCH model for all observed periods, for each observed market (North America, Croatia and Serbia), and in all observed periods (the entire period, pre-crisis, crisis and post-crisis periods). Figure 1 shows the movement of residual trends of the DJIA index for the reference period 2005-2017. Table 2 shows the estimated parameters of the optimal modified GARCH models for DJIA stock indeks in all observed periods (the entire period, pre-crisis, crisis and post-crisis periods).

Table 1. Representative AIC, SIC and HQC criteria for selecting the optimal modified GARCH model

\begin{tabular}{|c|c|c|c|c|c|c|c|c|c|}
\hline \multirow{2}{*}{$\begin{array}{l}\text { Period of } \\
\text { observation }\end{array}$} & \multicolumn{3}{|c|}{ modified GARCH 1.1} & \multicolumn{3}{|c|}{ modified TARCH } & \multicolumn{3}{|c|}{ modified EGARCH } \\
\hline & AIC & SIC & HQC & AIC & SIC & HQC & AIC & SIC & HQC \\
\hline ENTIRE PERIOD & 2.204026 & 2.356902 & 2.266148 & 2.131012 & 2.305728 & 2.202009 & 2.118902 & 2.293617 & 2.189898 \\
\hline PRE-CRISIS & 1.949157 & 2.301050 & 2.071977 & 2.049729 & 2.445609 & 2.187902 & 2.006796 & 2.402675 & 2.144968 \\
\hline CRISIS & 3.433145 & 3.785039 & 3.555966 & 3.534625 & 3.930504 & 3.672797 & 3.479265 & 3.875145 & 3.617438 \\
\hline POST-CRISIS & 1.983057 & 2.262303 & 2.092285 & 2.301983 & 2.616135 & 2.424865 & 2.242336 & 2.556488 & 2.365218 \\
\hline
\end{tabular}

Source: the authors' calculations 


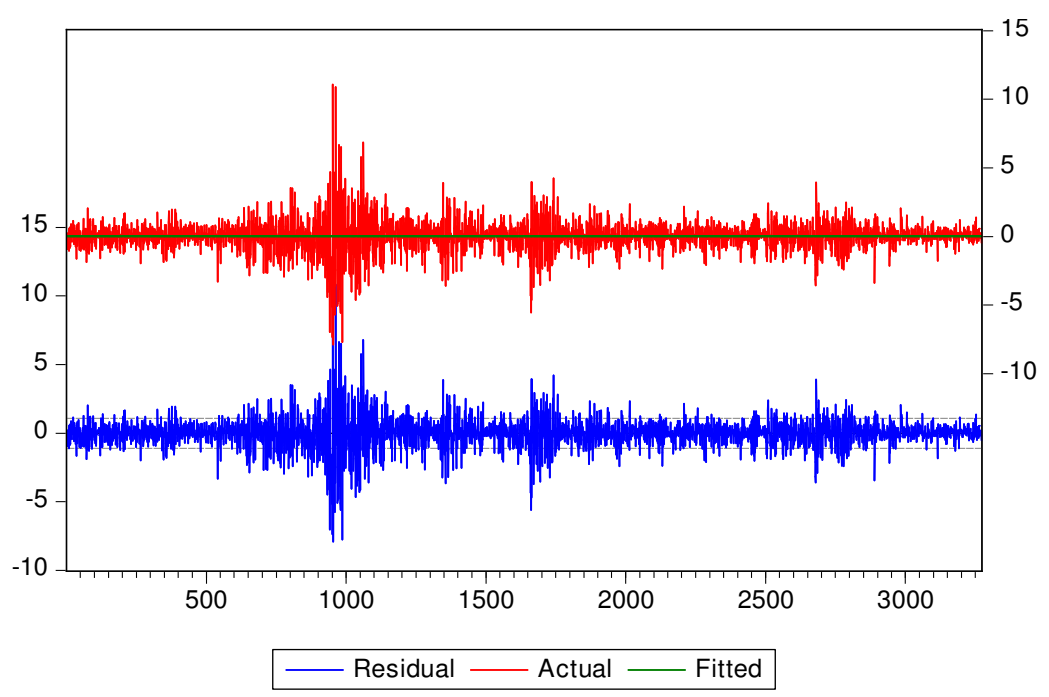

Source: the authors' calculations

Figure 1. Residual trends of the DJIA index for the reference period 2005-2017

Table 2. Estimated parameters of the optimal modified GARCH models for the DJIA stock index in different reference periods

\begin{tabular}{|c|c|c|c|c|c|c|c|}
\hline \multicolumn{2}{|c|}{ DJIA ENTIRE PERIOD } & \multicolumn{2}{|c|}{ DJIA PRE-CRISIS PERIOD } & \multicolumn{2}{|c|}{$\begin{array}{l}\text { DJIA CRISIS } \\
\text { PERIOD }\end{array}$} & \multicolumn{2}{|c|}{ DJIA POST-CRISIS } \\
\hline \multicolumn{2}{|c|}{$\begin{array}{l}\text { Variance Equation } \\
\text { modified EGARCH }\end{array}$} & \multicolumn{2}{|c|}{$\begin{array}{c}\text { Variance Equation } \\
\text { modified GARCH 1.1 }\end{array}$} & \multicolumn{2}{|c|}{$\begin{array}{c}\text { Variance Equation } \\
\text { modified GARCH } 1.1\end{array}$} & \multicolumn{2}{|c|}{$\begin{array}{c}\text { Variance Equation } \\
\text { modified GARCH } \\
\mathbf{1 . 1} \\
\end{array}$} \\
\hline GB & $\begin{array}{c}-0.010604 \\
(0.5823)\end{array}$ & $\mathrm{C}$ & $\begin{array}{c}-4.649994 \\
(0.1416)\end{array}$ & $\mathrm{C}$ & $\begin{array}{l}3.815652 \\
(0.0552)^{*}\end{array}$ & $\mathrm{C}$ & $\begin{array}{c}-0.466115 \\
(0.3040)\end{array}$ \\
\hline INFL & $\begin{array}{c}0.019628 \\
(0.5795)\end{array}$ & GB & $\begin{array}{l}0.244733 \\
(0.1486)\end{array}$ & GB & $\begin{array}{l}1.517677 \\
(0.0204)^{*}\end{array}$ & GB & $\begin{array}{c}0.860879 \\
(0.4736)\end{array}$ \\
\hline IR & $\begin{array}{c}-0.022911 \\
(0.4600)\end{array}$ & INFL & $\begin{array}{c}0.224754 \\
(0.3337)\end{array}$ & INFL & $\begin{array}{l}-0.254500 \\
(0.0443)^{*}\end{array}$ & INFL & $\begin{array}{c}-0.184704 \\
(0.1276)\end{array}$ \\
\hline ER & $\begin{array}{l}1183.823 \\
(0.1271)\end{array}$ & IR & $\begin{array}{l}1.411667 \\
(0.2255)\end{array}$ & IR & $\begin{array}{l}-1.824867 \\
(0.0578)^{*}\end{array}$ & IR & $\begin{array}{l}6.968319 \\
(0.0542)^{*}\end{array}$ \\
\hline- & ( & ER & $\begin{array}{c}-957.4376 \\
(0.5339)\end{array}$ & ER & $\begin{array}{c}-191.8939 \\
(0.8945)\end{array}$ & ER & $\begin{array}{c}44.20925 \\
(0.9396)\end{array}$ \\
\hline
\end{tabular}

where: C represents the GARCH constant; GB - ST Government bonds, INFL - Inflation rate, IR - Federal funds rate, $\mathrm{ER}$ - exchange rate, $\mathrm{P}$ - values are given in parentheses below each coefficient value, while ** and * represent statistical significance of $10 \%$ and $5 \%$ respectively.

Source: the authors' calculations

The selection of the best model based on the given criteria is the evidence of the impact of macroeconomic factors on the daily return rates of the DJIA stock exchange index. In the entire period, the modified EGARCH model with the lowest SIC criterium is most favourable, while in the pre-crisis, crisis and post-crisis periods, the modified GARCH 1.1 model is optimal.
In the observed periods (the entire period, pre-crisis, crisis and post-crisis periods), various positive and negative impacts of macroeconomic factors (e.g. inflation rate, interest rates on government bonds, reference interest rates and foreign exchange rates) on daily return rates of investment activities are recorded.

In the entire observation period, the 
modified EGARCH model shows negative impacts of government bonds (-0.010604) and the reference interest rate $(-0.022911)$ on the daily return rates of the observed index, while the inflation rate $(0.019628)$ and the exchange rate (1183.823) have positive impacts. In the pre-crisis period, the obtained results of the modified GARCH 1.1 model show positive impacts of the inflation rate $(0.224754)$, the reference interest rates (1.411667) and the interest rates on government bonds (0.244733), while the exchange rate (-957.4376) has a negative impact on the daily return rates. In the crisis period, the modified GARCH 1.1 model shows a significant positive effect of the interest rate on government bonds (1.517677), while the inflation rate $(-0.254500)$, the reference interest rate $(-1.824867)$ and the reference interest rate $(-1.824867)$ have a significant negative impact on the daily return rates. In the postcrisis period, the modified GARCH 1.1 model shows the positive impact of the exchange rate (44.20925), significant impacts of the reference interest rate (6.968319) and interest rates on government bonds (0.860879), while the inflation rate $(-0.184704)$ has a negative impact on the daily return rates of the DJIA stock exchange index. Table 3 shows the distribution of the daily residual returns of the DJIA sample in all observed periods (the entire period, precrisis, crisis and post-crisis periods). Table 4 shows the representative AIC, SIC and HQC criteria for selecting the optimal modified GARCH models in all observed periods (the entire period, pre-crisis, crisis and post-crisis periods) for DJIA. Figure 2 shows the movement of residual trends of the BELEX 15 index for the reference period 2005-2017. Table 5 shows the estimated parameters of

Table 3. Distribution of the daily residual returns of the DJIA sample in different observation periods

\begin{tabular}{|c|c|c|c|c|c|c|c|}
\hline \multicolumn{2}{|c|}{ DJIA ENTIRE PERIOD } & \multicolumn{2}{|c|}{ DJIA PRE-CRISIS } & \multicolumn{2}{|c|}{ DJIA CRISIS } & \multicolumn{2}{|c|}{ DJIA POST- CRISIS } \\
\hline \multicolumn{2}{|c|}{$\begin{array}{l}\text { Series: Standardized } \\
\text { Residuals }\end{array}$} & \multicolumn{2}{|c|}{$\begin{array}{l}\text { Series: Standardized } \\
\text { Residuals }\end{array}$} & \multicolumn{2}{|c|}{$\begin{array}{l}\text { Series: Standardized } \\
\text { Residuals }\end{array}$} & \multicolumn{2}{|c|}{$\begin{array}{l}\text { Series: Standardized } \\
\text { Residuals }\end{array}$} \\
\hline \multicolumn{2}{|c|}{ Sample 1132} & \multicolumn{2}{|c|}{ Sample 136} & \multicolumn{2}{|c|}{ Sample 136} & \multicolumn{2}{|c|}{ Sample 160} \\
\hline \multicolumn{2}{|c|}{ Observations 132} & \multicolumn{2}{|c|}{ Observations 36} & \multicolumn{2}{|c|}{ Observations 36} & \multicolumn{2}{|c|}{ Observations 60} \\
\hline Mean & 0.025624 & Mean & 0.044618 & Mean & -0.128663 & Mean & 0.022988 \\
\hline Median & 0.091635 & Median & 0.150862 & Median & -0.145821 & Median & 0.103759 \\
\hline Maximum & 2.129592 & Maximum & 1.759645 & Maximum & 1.978972 & Maximum & 2.003185 \\
\hline Minimum & -2.534731 & Minimum & -2.001873 & Minimum & -2.160732 & Minimum & -3.091871 \\
\hline Std. Dev. & 0.998816 & Std. Dev. & 0.996560 & Std. Dev. & 1.036232 & Std. Dev. & 1.013854 \\
\hline Skewness & -0.150476 & Skewness & -0.233625 & Skewness & 0.007728 & Skewness & -0.696897 \\
\hline Kurtosis & 2.504311 & Kurtosis & 2.195673 & Kurtosis & 2.354758 & Kurtosis & 3.693959 \\
\hline Jarque-Bera & 1.849539 & Jarque-Bera & 1.297897 & Jarque-Bera & 0.624865 & Jarque-Bera & 6.060601 \\
\hline Probability & 0.396623 & Probability & 0.522595 & Probability & 0.731665 & Probability & 0.048301 \\
\hline
\end{tabular}

Table 4. Representative AIC, SIC and HQC criteria for selecting the optimal modified GARCH models

\begin{tabular}{|c|c|c|c|c|c|c|c|c|c|}
\hline \multirow{2}{*}{$\begin{array}{l}\text { Period of } \\
\text { observation }\end{array}$} & \multicolumn{3}{|c|}{ modified GARCH 1.1} & \multicolumn{3}{|c|}{ modified TARCH } & \multicolumn{3}{|c|}{ modified EGARCH } \\
\hline & AIC & SIC & HQC & AIC & SIC & HQC & AIC & SIC & HQC \\
\hline ENTIRE PERIOD & 2.017470 & 2.192186 & 2.088467 & 1.957620 & 2.154175 & 2.037491 & 1.970023 & 2.166578 & 2.049894 \\
\hline PRE-CRISIS & 1.723208 & 2.075101 & 1.846028 & 1.712357 & 2.108237 & 1.850530 & 1.837832 & 2.233712 & 1.976005 \\
\hline CRISIS & 3.735248 & 4.087141 & 3.858068 & 3.727171 & 4.123051 & 3.865344 & 3.787140 & 4.183020 & 3.925313 \\
\hline POST-CRISIS & 2.695593 & 2.974839 & 2.804821 & 2.708626 & 3.022777 & 2.831508 & 2.718486 & 3.032637 & 2.841368 \\
\hline
\end{tabular}




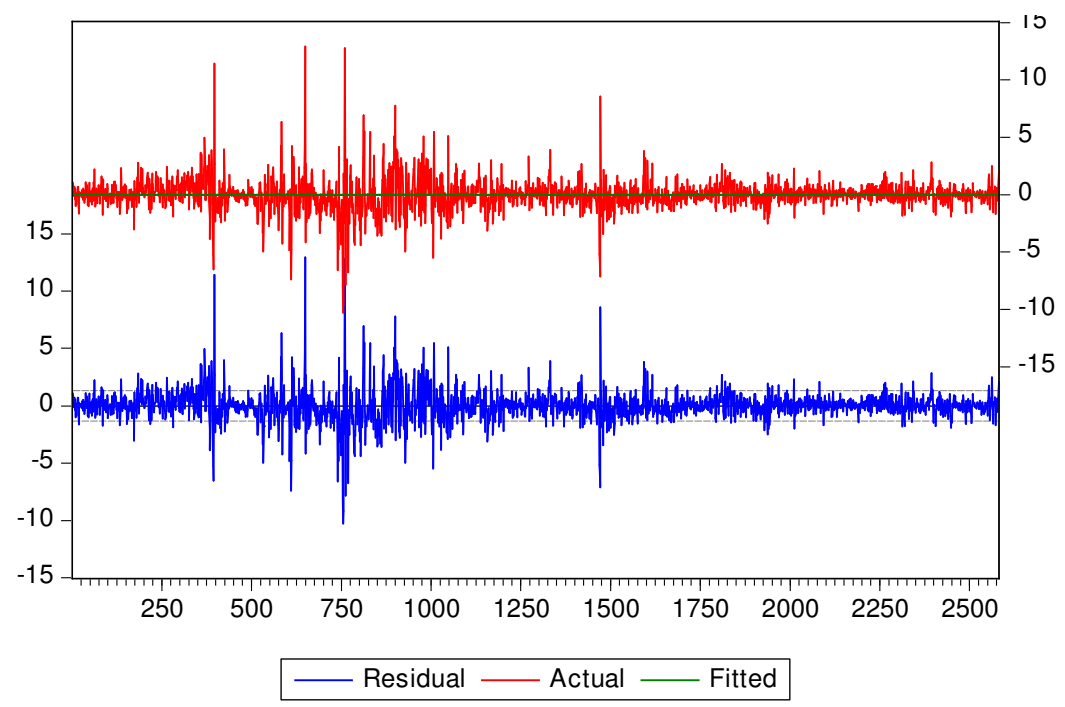

Source: the authors' calculations

Figure 2. Residual trends of the BELEX15 index for the reference period 2005-2017

Table 5. Estimated parameters of the optimal modified GARCH models for the BELEX15 stock index in different reference periods

\begin{tabular}{|c|c|c|c|c|c|c|c|}
\hline \multicolumn{2}{|c|}{$\begin{array}{c}\text { BELEX15 } \\
\text { ENTIRE PERIOD }\end{array}$} & \multicolumn{2}{|c|}{$\begin{array}{c}\text { BELEX15 } \\
\text { PRE-CRISIS }\end{array}$} & \multicolumn{2}{|c|}{$\begin{array}{l}\text { BELEX15 } \\
\text { CRISIS }\end{array}$} & \multicolumn{2}{|c|}{$\begin{array}{c}\text { BELEX15 } \\
\text { POST-CRISIS }\end{array}$} \\
\hline \multicolumn{2}{|c|}{$\begin{array}{l}\text { Variance Equation } \\
\text { modified TARCH }\end{array}$} & \multicolumn{2}{|c|}{$\begin{array}{c}\text { Variance Equation } \\
\text { modified GARCH 1.1 }\end{array}$} & \multicolumn{2}{|c|}{$\begin{array}{c}\text { Variance Equation } \\
\text { modified GARCH 1.1 }\end{array}$} & \multicolumn{2}{|c|}{$\begin{array}{c}\text { Variance Equation } \\
\text { modified GARCH 1.1 }\end{array}$} \\
\hline $\mathrm{C}$ & $\begin{array}{c}-0.268895 \\
(0.4673)\end{array}$ & $\mathrm{C}$ & $\begin{array}{c}-36.78563 \\
(0.2559)\end{array}$ & $\mathrm{C}$ & $\begin{array}{c}-0.698381 \\
(0.6117)\end{array}$ & $\mathrm{C}$ & $\begin{array}{c}-0.943855 \\
(0.3566)\end{array}$ \\
\hline GB & $\begin{array}{c}0.021794 \\
(0.1859)\end{array}$ & GB & $\begin{array}{l}0.056089 \\
(0.0001)^{*}\end{array}$ & GB & $\begin{array}{l}-0.085856 \\
(0.0003)^{*}\end{array}$ & GB & $\begin{array}{l}-0.107251 \\
(0.0965)^{* *}\end{array}$ \\
\hline INFL & $\begin{array}{c}-0.017582 \\
(0.1321)\end{array}$ & INFL & $\begin{array}{l}-0.048779 \\
(0.0001)^{*}\end{array}$ & INFL & $\begin{array}{c}-0.013995 \\
(0.6887)\end{array}$ & INFL & $\begin{array}{c}-0.016475 \\
(0.7112)\end{array}$ \\
\hline IR & $\begin{array}{c}0.029814 \\
(0.4226)\end{array}$ & IR & $\begin{array}{c}4.316252 \\
(0.2580)\end{array}$ & IR & $\begin{array}{c}0.164423 \\
(0.3572)\end{array}$ & IR & $\begin{array}{c}0.219645 \\
(0.0760)^{* *}\end{array}$ \\
\hline ER & $\begin{array}{c}1.439192 \\
(0.5980)\end{array}$ & ER & $\begin{array}{l}8.513668 \\
(0.0090)^{*}\end{array}$ & ER & $\begin{array}{l}-3.009215 \\
(0.0975)^{* *}\end{array}$ & ER & $\begin{array}{c}0.678330 \\
(0.8209)\end{array}$ \\
\hline
\end{tabular}

where: C represents the GARCH constant; GB - ST Government bonds, INFL - Inflation rate, IR - Interest rate of $\mathrm{CB}, \mathrm{ER}$ - exchange rate, $\mathrm{P}$ - values are given in parentheses below each coefficient value, while $* *$ and $*$ represent statistical significance of $10 \%$ and $5 \%$ respectively.

Source: the authors' calculations

the optimal modified GARCH models for BELEX 15 stock indeks in all observed periods (the entire period, pre-crisis, crisis and post-crisis periods).

For the entire observed period 2005-2017, there is no normal distribution. The average daily return is positive, while the only negative average daily return is recorded in the crisis period, which is a feature of the developed financial markets. Elongated distributions and negative asymmetry are characteristics of developed financial markets. As for other periods, the different normality distribution assessments of the 
observed periods are noticeable, which indicates a small number of observations, as well as a stronger impact of macroeconomic factors on the daily rates of return of the DJIA stock exchange index.

In the following section, the case study of the emerging financial market - Serbia will be presented via BELEX15 index.

Table 6 shows the distribution of the daily residual returns of the BELEX 15 sample in all observed periods (the entire period, precrisis, crisis and post-crisis periods). Table 7 shows the representative AIC, SIC and HQC criteria for selecting the optimal modified GARCH models in all observed periods (the entire period, pre-crisis, crisis and post-crisis periods) for BELEX 15. Figure 3 shows the movement of residual trends of the CROBEX index for the reference period 2005-2017.
The selection of the best model based on the given criteria is the evidence of the impact of macroeconomic factors on the daily return rates of the BELEX15 stock exchange index. In the entire period, the modified TARCH model with the lowest SIC criterium is most favourable, while in the pre-crisis, crisis and post-crisis periods, the modified GARCH 1.1 model is optimal. In the observed periods (the entire period, precrisis, crisis and post-crisis periods), various positive and negative impacts of macroeconomic factors (e.g. inflation rate, interest rates on government bonds, reference interest rates and foreign exchange rates) on daily return rates of investment activities are recorded.

Table 8 shows the estimated parameters of the optimal modified GARCH models for CROBEX stock indeks in all observed

Table 6. Distribution of the daily residual returns of the BELEX15 sample in different observation periods

\begin{tabular}{|c|c|c|c|c|c|c|c|}
\hline \multicolumn{2}{|c|}{$\begin{array}{c}\text { BELEX15 } \\
\text { ENTIRE PERIOD }\end{array}$} & \multicolumn{2}{|c|}{ BELEX15 } & \multicolumn{2}{|c|}{ BELEX15 } & \multicolumn{2}{|c|}{ BELEX15 } \\
\hline \multicolumn{2}{|c|}{$\begin{array}{l}\text { Series: Standardized } \\
\text { Residuals }\end{array}$} & \multicolumn{2}{|c|}{$\begin{array}{l}\text { Series: Standardized } \\
\text { Residuals }\end{array}$} & \multicolumn{2}{|c|}{$\begin{array}{l}\text { Series: Standardized } \\
\text { Residuals }\end{array}$} & \multicolumn{2}{|c|}{$\begin{array}{l}\text { Series: Standardized } \\
\text { Residuals }\end{array}$} \\
\hline \multicolumn{2}{|c|}{ Sample 1132} & \multicolumn{2}{|c|}{ Sample 136} & \multicolumn{2}{|c|}{ Sample 136} & \multicolumn{2}{|c|}{ Sample 160} \\
\hline \multicolumn{2}{|c|}{ Observations 132} & \multicolumn{2}{|c|}{ Observations 36} & \multicolumn{2}{|c|}{ Observations 36} & \multicolumn{2}{|c|}{ Observations 60} \\
\hline Mean & -0.002485 & Mean & -0.055772 & Mean & -0.003466 & Mean & 0.016883 \\
\hline Median & 0.002551 & Median & -0.036577 & Median & -0.085005 & Median & 0.006710 \\
\hline Maximum & 2.834781 & Maximum & 1.791820 & Maximum & 2.312322 & Maximum & 2.314131 \\
\hline Minimum & -3.138156 & Minimum & -1.842113 & Minimum & -1.657383 & Minimum & -2.014683 \\
\hline Std. Dev. & 1.004757 & Std. Dev. & 1.010322 & Std. Dev. & 1.012129 & Std. Dev. & 1.006500 \\
\hline Skewness & -0.113126 & Skewness & -0.052031 & Skewness & 0.491254 & Skewness & 0.245914 \\
\hline Kurtosis & 3.161535 & Kurtosis & 2.197007 & Kurtosis & 2.847106 & Kurtosis & 2.548266 \\
\hline Jarque-Bera & 0.425060 & Jarque-Bera & 0.983440 & Jarque-Bera & 1.483045 & Jarque-Bera & 1.114897 \\
\hline Probability & 0.808536 & Probability & 0.611574 & Probability & 0.476388 & Probability & 0.572668 \\
\hline
\end{tabular}

Table 7. Representative AIC, SIC and HQC criteria for selecting the optimal modified GARCH models

\begin{tabular}{|c|c|c|c|c|c|c|c|c|c|}
\hline \multirow{2}{*}{$\begin{array}{l}\text { Period of } \\
\text { observation }\end{array}$} & \multicolumn{3}{|c|}{ modified GARCH 1.1} & \multicolumn{3}{|c|}{ modified TARCH } & \multicolumn{3}{|c|}{ modified EGARCH } \\
\hline & AIC & SIC & HQC & AIC & SIC & HQC & AIC & SIC & HQC \\
\hline ENTIRE PERIOD & 3.278280 & 3.452995 & 3.349276 & 3.238323 & 3.434878 & 3.318194 & 3.189942 & 3.386497 & 3.269813 \\
\hline PRE-CRISIS & 3.726790 & 4.078683 & 3.849610 & 4.151970 & 4.547849 & 4.290142 & 3.650683 & 4.046563 & 3.788855 \\
\hline CRISIS & 4.133654 & 4.485547 & 4.256474 & 4.245065 & 4.640945 & 4.383238 & 4.190480 & 4.586359 & 4.328652 \\
\hline POST-CRISIS & 2.389567 & 2.741460 & 2.512387 & 2.439398 & 2.835278 & 2.577571 & 2.413421 & 2.809301 & 2.551593 \\
\hline
\end{tabular}




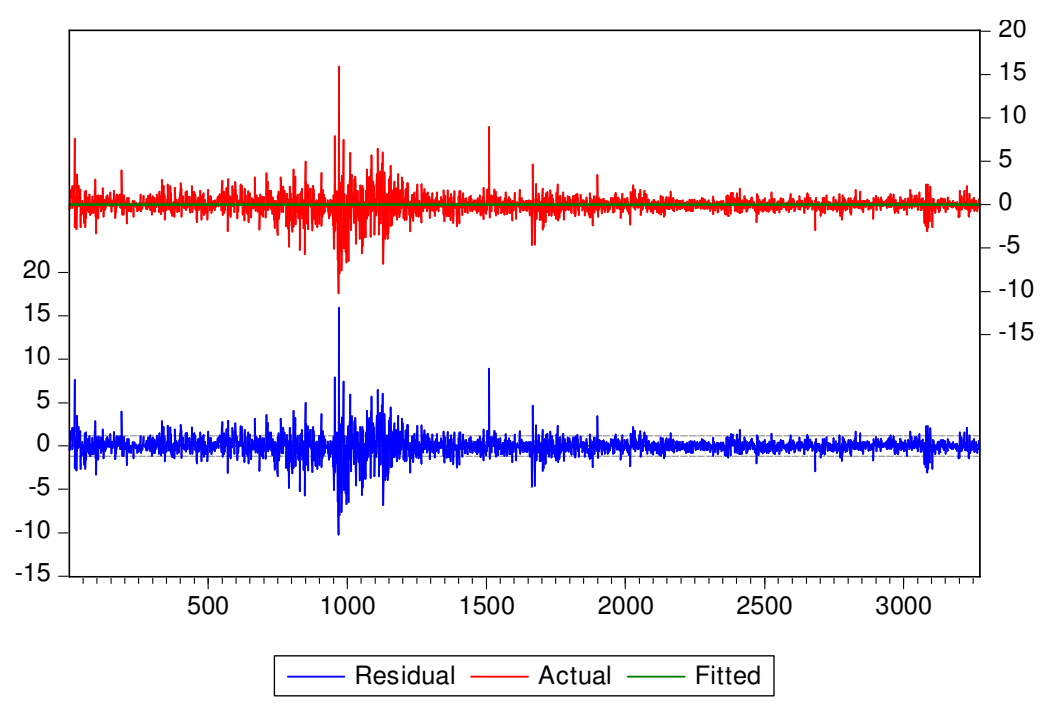

Source: the authors' calculations

Figure 3. Residual trends of the CROBEX index for the reference period 2005-2017

Table 8. Estimated parameters of the optimal modified GARCH models for the CROBEX stock index in different reference periods

\begin{tabular}{|c|c|c|c|c|c|c|c|}
\hline \multicolumn{2}{|c|}{$\begin{array}{l}\text { CROBEX ENTIRE } \\
\text { PERIOD }\end{array}$} & \multicolumn{2}{|c|}{$\begin{array}{l}\text { CROBEX PRE-CRISIS } \\
\text { PERIOD }\end{array}$} & \multicolumn{2}{|c|}{ CROBEX CRISIS PERIOD } & \multicolumn{2}{|c|}{$\begin{array}{l}\text { CROBEX POST- } \\
\text { CRISIS }\end{array}$} \\
\hline \multicolumn{2}{|c|}{$\begin{array}{l}\text { Variance Equation } \\
\text { modified EGARCH }\end{array}$} & \multicolumn{2}{|c|}{$\begin{array}{c}\text { Variance Equation } \\
\text { modified EGARCH }\end{array}$} & \multicolumn{2}{|c|}{$\begin{array}{c}\text { Variance Equation } \\
\text { modified GARCH 1.1 }\end{array}$} & \multicolumn{2}{|c|}{$\begin{array}{c}\text { Variance Equation } \\
\text { modified GARCH 1.1 }\end{array}$} \\
\hline $\mathrm{C}$ & $\begin{array}{l}0.771943 \\
(0.0000)^{*}\end{array}$ & $\mathrm{C}$ & $\begin{array}{l}0.292547 \\
(0.4677)\end{array}$ & $\mathrm{C}$ & $\begin{array}{l}14.70197 \\
(0.9500)\end{array}$ & $\mathrm{C}$ & $\begin{array}{c}-1.305757 \\
(0.3783)\end{array}$ \\
\hline GB & $\begin{array}{c}-0.032196 \\
(0.3603)\end{array}$ & GB & $\begin{array}{c}-0.021339 \\
(0.2365)\end{array}$ & GB & $\begin{array}{l}0.170421 \\
(0.4414)\end{array}$ & GB & $\begin{array}{l}0.028813 \\
(0.8112)\end{array}$ \\
\hline INFL & $\begin{array}{c}-0.055451 \\
(0.1289)\end{array}$ & INFL & $\begin{array}{l}1.196713 \\
(0.0000)^{*}\end{array}$ & INFL & $\begin{array}{l}0.024333 \\
(0.8739)\end{array}$ & $\begin{array}{c}\text { INF } \\
\text { L }\end{array}$ & $\begin{array}{l}0.145336 \\
(0.0088)^{*}\end{array}$ \\
\hline IR & $\begin{array}{l}-0.066062 \\
(0.0000)^{*}\end{array}$ & IR & $\begin{array}{l}-0.785784 \\
(0.0000)^{*}\end{array}$ & IR & $\begin{array}{l}-1.818560 \\
(0.9444)\end{array}$ & IR & $\begin{array}{l}0.125401 \\
(0.5189)\end{array}$ \\
\hline ER & $\begin{array}{c}-184.9244 \\
(0.3323)\end{array}$ & ER & $\begin{array}{l}-504.1072 \\
(0.0000)^{*}\end{array}$ & ER & $\begin{array}{l}8.033765 \\
(0.9892)\end{array}$ & ER & $\begin{array}{c}2.468430 \\
(0.9908)\end{array}$ \\
\hline
\end{tabular}

where: C represents the GARCH constant; GB - ST Government bonds, INFL - Inflation rate, IR - Interest rate of $\mathrm{CB}, \mathrm{ER}$ - exchange rate, $\mathrm{P}$ - values are given in parentheses below each coefficient value, while ** and * represent statistical significance of $10 \%$ and $5 \%$ respectively.

Source: the authors' calculations

periods (the entire period, pre-crisis, crisis and post-crisis periods).

In the entire observation period, the modified TARCH model shows a negative impact of the inflation rate $(-0.048779)$ on the daily return rates of the observed index, while the reference interest rate (0.029814), the interest rate on government bonds
(0.021794) and the exchange rate (1.439192) have positive impacts. In the pre-crisis period, the obtained results of the modified GARCH 1.1 model show positive impacts of the reference interest rate (4.316252), a significant impact of the interest rate on government bonds $(0.056089)$ and exchange rate (8.513668), while the inflation rate 
$(-0.048779)$ has a negative impact on the daily return rates. In the crisis period, the modified GARCH 1.1 model shows the positive impact of the reference interest rate $(0.164423)$, while the inflation rate $(-0.013995)$, the interest rate on government bonds $(-0.085856)$ and the exchange rate $(-3.009215)$ record a significant negative impact on the daily return rates. In the postcrisis period, the modified GARCH 1.1 model shows significant positive impacts of the reference interest rate $(0.219645)$ and the exchange rate $(0.678330)$, while the inflation rate $(-0.016475)$ and the interest rate on government bonds $(-0.107251)$ have a significant negative impact on the daily return rates of the BELEX15 index.

For the entire observed period 2005-2017, there is no normal distribution. The average daily return is negative, while the only positive average daily return is recorded in the post-crisis period, which is a feature of the emerging financial markets. The less elongated distributions are characteristic for emerging financial markets. As for other periods, the different normality distribution assessments of the observed periods are noticeable, which indicates a small number of observations, as well as a stronger impact of macroeconomic factors on the daily rates of return of the BELEX15 stock exchange index.

Table 9 shows the distribution of the daily residual returns of the CROBEX sample in all observed periods (the entire period, precrisis, crisis and post-crisis periods).

In the following text, the case study of the emerging financial market - Croatia will be presented, via CROBEX index.

Table 10 shows the comparative overview of the obtained research result. The table shows the most optimal GARCH models (according to the lowest value of the SIC information criterion) for the observed financial markets in all observed periods (the entire period, pre-crisis, crisis and post-crisis periods).

The selection of the best model based on the given criteria is the evidence of the impact of macroeconomic factors on the daily return rates of the CROBEX stock exchange index. In the entire period and the pre-crisis period, the modified EGARCH model with the lowest SIC criterium is most

Table 9. Distribution of the daily residual returns of the CROBEX sample in different observation periods

\begin{tabular}{|c|c|c|c|c|c|c|c|}
\hline \multicolumn{2}{|c|}{$\begin{array}{l}\text { CROBEX - ENTIRE } \\
\text { PERIOD }\end{array}$} & \multicolumn{2}{|c|}{ CROBEX - PRE-CRISIS } & \multicolumn{2}{|c|}{ CROBEX - CRISIS } & \multicolumn{2}{|c|}{ CROBEX - POST-CRISIS } \\
\hline \multirow{2}{*}{\multicolumn{2}{|c|}{$\begin{array}{l}\text { Series: Standardized } \\
\text { Residuals }\end{array}$}} & \multirow{2}{*}{\multicolumn{2}{|c|}{$\begin{array}{l}\text { Series: Standardized } \\
\text { Residuals }\end{array}$}} & \multirow{2}{*}{\multicolumn{2}{|c|}{$\begin{array}{l}\text { Series: Standardized } \\
\text { Residuals }\end{array}$}} & \multirow{2}{*}{\multicolumn{2}{|c|}{$\begin{array}{l}\text { Series: Standardized } \\
\text { Residuals }\end{array}$}} \\
\hline & & & & & & & \\
\hline \multicolumn{2}{|c|}{ Sample 1132} & \multicolumn{2}{|c|}{ Sample 136} & \multicolumn{2}{|c|}{ Sample 136} & \multicolumn{2}{|c|}{ Sample 136} \\
\hline \multicolumn{2}{|c|}{ Observations 132} & \multicolumn{2}{|c|}{ Observations 36} & \multicolumn{2}{|c|}{ Observations 36} & \multicolumn{2}{|c|}{ Observations 36} \\
\hline Mean & 0.007468 & Mean & 0.063395 & Mean & -0.029280 & Mean & -0.091997 \\
\hline Median & -0.023179 & Median & 0.102441 & Median & -0.062373 & Median & -0.037263 \\
\hline Maximum & 3.369068 & Maximum & 2.615667 & Maximum & 2.064534 & Maximum & 1.802336 \\
\hline Minimum & -2.581103 & Minimum & -3.410593 & Minimum & -2.024604 & Minimum & -2.353226 \\
\hline Std. Dev. & 1.023446 & Std. Dev. & 1.040244 & Std. Dev. & 1.027746 & Std. Dev. & 1.006767 \\
\hline Skewness & -0.045812 & Skewness & -0.701382 & Skewness & 0.183629 & Skewness & -0.156607 \\
\hline Kurtosis & 3.743333 & Kurtosis & 6.213207 & Kurtosis & 2.491447 & Kurtosis & 2.661557 \\
\hline Jarque-Bera & 5.531932 & Jarque-Bera & 18.43868 & Jarque-Bera & 0.590256 & Jarque-Bera & 0.318970 \\
\hline Probability & 0.062915 & Probability & 0.000000 & Probability & 0.744436 & Probability & 0.852583 \\
\hline
\end{tabular}


Table 10. Comparative overview of the obtained research results

\begin{tabular}{|c|c|c|c|c|c|}
\hline \multicolumn{6}{|c|}{ DJIA } \\
\hline Model & Period & GB & INFL & IR & ER \\
\hline m EGARCH & Entire & -0.010 & 0.0196 & -0.022 & 1183.8 \\
\hline m GARCH 1.1 & Pre-Crisis & 0.2444 & 0.2247 & 1.4116 & -957.4 \\
\hline m GARCH 1.1 & Crisis & $1.5176^{*}$ & $-0.254 *$ & $-1.824 *$ & -191.8 \\
\hline m GARCH 1.1 & Post-Crisis & 0.8608 & -0.184 & $6.9683^{*}$ & 44.209 \\
\hline \multicolumn{6}{|c|}{ BELEX15 } \\
\hline Model & Period & GB & INFL & IR & ER \\
\hline m TARCH & Entire & 0.0217 & -0.017 & 0.0298 & 1.4391 \\
\hline m GARCH 1.1 & Pre-Crisis & $0.0560 *$ & -0.048 & 4.3162 & $8.5136^{*}$ \\
\hline m GARCH 1.1 & Crisis & $-0.085^{*}$ & -0.013 & 0.1644 & $-3.009 * *$ \\
\hline m GARCH 1.1 & Post-Crisis & $-0.107 * *$ & -0.016 & $0.2196 * *$ & 0.6783 \\
\hline \multicolumn{6}{|c|}{ CROBEX } \\
\hline Model & Period & GB & INFL & IR & ER \\
\hline m EGARCH & Entire & -0.032 & -0.055 & $-0.066^{*}$ & -184.9 \\
\hline m EGARCH & Pre-Crisis & -0.021 & $1.1967 *$ & $-0.785^{*}$ & $-504.1^{*}$ \\
\hline m GARCH 1.1 & Crisis & 0.1704 & 0.0243 & -1.818 & 8.033 \\
\hline m GARCH 1.1 & Post-Crisis & 0.0288 & $0.1453 *$ & 0.1254 & 2.468 \\
\hline
\end{tabular}

*Statistical significance of $5 \%$.

$* *$ Statistical significance of $10 \%$.

Source: the authors' calculations

favourable, while in the crisis and post-crisis periods, the modified GARCH 1.1 model is optimal. In the observed periods (the entire period, pre-crisis, crisis and post-crisis periods), various positive and negative impacts of macroeconomic factors on daily return rates of investment activities are recorded, such as inflation rate, interest rates on government bonds, reference interest rates and foreign exchange rates.

In the entire observation period, the modified EGARCH model shows negative impacts of the inflation rate $(-0.055451)$, reference interest rates $(-0.066062$ significant impact), interest rates on government bonds (-0.032196) and foreign exchange rate $(-184.9244)$ on the daily return rates of the observed index. In the pre-crisis period, the obtained results of the modified EGARCH model show a significant positive impact of the inflation rate (1.196713), while the interest rate on government bonds $(-0.021339)$, the reference interest rate $(-0.785784)$ and the exchange rate (-504.1072 - significant effect) have negative impacts on the daily return rates. In the crisis period, the modified GARCH 1.1 model shows a negative impact of the reference interest rate $(-1.818560)$, while the inflation rate $(0.024333)$, the interest rate on government bonds (0.170421) and the exchange rate (8.033765) have positive impacts on the daily return rates. In the postcrisis period, the modified GARCH 1.1 model shows the positive effects of the inflation rate $(0.145336$ - significant $)$, reference interest rates $(0.125401)$, interest rates on government bonds $(0.028813)$ and exchange rate $(2.468430)$ on the daily return rates of the CROBEX stock exchange index.

For the entire observed period 2005-2017, there is no normal distribution. The average 
daily returns are positive in the entire and pre-crisis periods, while the negative average daily returns are recorded in the crisis and post-crisis periods. The less elongated distributions are characteristic for emerging financial markets. Kurtosis coefficients are above average in the entire and pre-crisis periods, which points to extreme return values and high investment risk. As for other periods, the different normality distribution assessments of the observed periods are noticeable, which indicates a small number of observations, as well as a stronger impact of macroeconomic factors on the daily rates of return of the CROBEX stock exchange index.

In the observed financial market of North America through the modified GARCH methodology, at no point, the exchange rate had a statistically significant impact on the daily return rates, which is not the case with the observed financial markets of developing countries, where statistically significant influence was recorded in the pre-crisis and crisis periods.

\section{CONCLUSION}

The research results indicate the importance of the modified GARCH methodology for quantification and optimization of macroeconomic factors in investment activities in modern business conditions. In practice, the research tests the role and significance of a modified GARCH methodology for estimating daily return rates in the case of the developed (North American financial market) and the financial markets in the developing countries of Croatia and Serbia. The authors emphasized the importance of the application analysis and optimisation of the modified GARCH methodology for investment activities in developed versus emerging financial markets.

The scientific contribution of the research is reflected in the quality and significance of research results and the possibilities of efficient application of the modified GARCH methodology. The modified GARCH methodology quantified the impact of macroeconomic factors, such as inflation rate, interest rates on government bonds, reference interest rates and exchange rates, on daily return rates from investment activities for the observed developed and emerging financial markets. The application of the modified GARCH methodology serves to manage the investment risk, which significantly extends the field of the research area. The practical contribution of the research is reflected in the expanded possibilities of efficient application of the modified GARCH methodology to the daily return rates in everyday investment decision making.

Assuming that the application of the modified GARCH methodology for quantifying the impact of the inflation rate, the interest rates on government bonds, the reference interest rates and the exchange rate on the daily return rates significantly contributes to investment risk reduction, the main $\mathrm{H} 0$ hypothesis has been confirmed. In the developed financial markets of North America, as well as in the financial markets in the developing countries of Serbia and Croatia, the correct correlation between the daily return rates of stock exchange indices and macroeconomic factors (inflation rate, reference interest rate, interest rate on government bonds and exchange rate) for all observed periods (the entire period, precrisis, crisis and post-crisis periods) has been confirmed. By introducing macroeconomic 
factors in GARCH models, the basic models are expanded and certainly made optimal. The obtained research results are more favourable and contribute to the optimization of the investment strategy. SIC information criteria were used to select the optimal GARCH model among all extensions of GARCH 1.1, TARCH and EGARCH in all observed financial markets and in all observed periods. It can be concluded that the same GARCH model cannot be used in each financial market to quantify the impact of macroeconomic factors that will have the optimal estimated model parameters. In addition, it can be concluded that the application of the modified GARCH methodology in both the developed and emerging markets has successfully tested the impact of macroeconomic factors and contributed to the optimization of the investment strategy with well-defined results of positive and negative impacts of macroeconomic factors on the daily return rates of stock exchange indices. The modified GARCH methodology significantly contributes to investment risk reduction in the observed financial markets.

Claiming that the application of a modified GARCH 1.1 model can be equally successfully applicable on both developed and emerging financial markets, the $\mathrm{H} 1$ hypothesis has also been confirmed. It means that the research results show that the custom GARCH 1.1 model is optimal for both the developed financial market of North America and the emerging markets of Serbia and Croatia in the crisis and post-crisis periods. Using the SIC information criteria, the comparative overview shows that the custom GARCH 1.1 model prevails in the developed financial market of North America in pre-crisis, crisis and post-crisis periods. The modified GARCH 1.1 proves itself as optimal for both the observed developed and emerging markets. In 8 out of 12 cases, it verified as optimal in the observed periods (pre-crisis, crisis and postcrisis periods).

Assuming that the modified GARCH 1.1 model is most effective for assessing the impact significance of certain tested macroeconomic factors, the $\mathrm{H} 2$ hypothesis has been confirmed. Using the modified GARCH 1.1 model, for the financial market of North America in the crisis period, statistically significant impacts of macroeconomic factors (e.g. the interest rates on government bonds, inflation rate and reference rates on daily returns) are recorded. In the post-crisis period, the results obtained by the modified GARCH 1.1 model show a statistically significant impact of the reference interest rate on daily returns. Furthermore, a statistically significant and quite large positive effect of the interest rate on government bonds in the crisis period is recorded, which proves that the daily returns also depend on the interest rates on government bonds. In the post-crisis period, in the observed financial markets of North America, Serbia and Croatia, the modified GARCH 1.1 model records a positive (statistically significant in the financial markets of North America and Serbia) impact of the reference interest rate on daily returns.

The aforementioned facts show the importance of a modified GARCH methodology to test the difference between the impact of macroeconomic factors on the return daily rates on the developed financial markets, in relation to those of developing countries, their various behaviours in certain market conditions and observation periods and contribute to investment risk reduction. The special quality of the research results 
stems from the fact that it is focused on the use of a new approach to the modified GARCH methodology in the developed and emerging markets, whilst the analysis of comparative literature in this research field shows a relatively small number of studies with this topic.

Both the basic and the specific goals are fully met by the research, with the modified GARCH methodology application tested in practice in the developed and emerging financial markets. The research has a wide period of time, i.e. it is focused on the periods before, during and after the outbreak of the global economic and financial crisis, which ensures the complete representativity of the obtained research results.

The testing of the impact of macroeconomic factors using the modified GARCH methodology has a fully scientific, i.e. academic contribution, which opens up opportunities for further research on the topic. The research results have multiple relevance, especially for domestic and international investors (institutional investors, investment funds, portfolio managers, market analysts and others), thus confirming the practical contribution of the research. The obtained results help domestic and international investors in the process of defining an optimal investment strategy, as well as making investment decisions in both developed and emerging financial markets. The research results indicate a practical contribution in terms of whether the appropriate investment strategy should be applied and in which markets, depending on the economic conditions (pre-crisis, crisis and post-crisis), in order to protect and reduce the risk of investment activities.

On the one hand, the research presents the problems and challenges arising from the specific characteristics of the financial markets of the developing countries, and on the other, the need to adapt the tested modified GARCH models to the specificities of these markets. The greatest challenge for this research was to implement and modify existing GARCH econometric models and quantify the impact of macroeconomic factors such as the inflation rate, interest rates on government bonds, reference interest rates and exchange rates in the observed developed and emerging markets, thus applying them successfully and obtaining results that are based on science and practice.

During the research process, specific problems and challenges in the financial markets, both in developed and developing countries, imposed the need to modify the GARCH methodology to the specificities of these markets. The main challenge of this research was to apply the modified GARCH econometric models and quantify the macroeconomic factors' impact on the observed markets, thus gaining the successful obtained results. Future research in this area should focus on extending the research to other financial markets of developing countries and comparing them with developed financial markets, thereby increasing the flexibility of the tested modified GARCH methodology in order to maximize the effects and reduce the risk of investment activity. In this regard, the focus of future research will be extended to the development of a methodology with a higher level of flexibility and adaptability, taking into account the dynamics of changes in financial markets caused by global trends. 


\title{
ПРИМЕНА МОДИФИКОВАНЕ GАRСН МЕТОДОЛОГИЈЕ: РАЗВИЈЕНА ФИНАНСИЈСКА ТРЖИШТА ПРОТИВ ФИНАНСИЈСКИХ ТРЖИШТА У РАЗВОЈУ
}

\author{
Ненад Пенезић, Горан Анђелић, Марко Р. Милошевић, Вилмош Тот
}

\section{Извод}

Предмет овог истраживања је анализа и тестирање модификоване GARCH методологије у смислу квантификовања утицаја стопа инфлације, каматних стопа на државне обвезнице, референтних каматних стопа и девизних курсева на дневне стопе приноса на инвестиционе активности на посматраним финансијским тржиштима Северне Америке, Србије и Хрватске. Циљ истраживања, односно посебан фокус у истраживању, је упоређивање добијених резултата између развијених финансијских тржишта и финансијских тржишта земаља у развоју, као и тестирање модификоване GARCH методологије на посматраним финансијским тржиштима. Кључни индикатори у истраживању, за које се претпоставља да утичу на дневне стопе поврата, били су следећи: стопа инфлације, каматне стопе на државне обвезнице, референтна каматна стопа и курс. Временски период обухваћен истраживањем је од 2005. до 2017. године, где ширина временског хоризонта истраживања омогућава тестирање модификоване GARCH методологије у периодима пре, током и после глобалне финансијске кризе. Поред употребе модификованих економетријских модела GARCH, методологија истраживања укључује употребу AIC, SIC и HQC (Akaike, Schwarz и Hannan-Quinn) критеријума за одабир најбољих модела, као и одговарајуће тестове који су погодни и/или прилагођени специфичним карактеристикама финансијских тржишта, како развијених, тако и земаља у развоју. Резултати истраживања потврђују улогу и значај модификоване GARCH методологије за ефикасно квантификовање инвестиционог ризика на развијеним финансијским тржиштима наспрам финансијских тржишта земаља у развоју. У том смислу, добијени резултати истраживања биће корисни и академској заједници и стручној јавности у контексту доношења одлука о улагању.

Кључне речи: GARCH, ризик, развијена финансијска тржишта, финансијска тржишта у развоју

\section{ACKNOWLEDGEMENT}

The work is a part of a research project titled: "Analysis of Financial Risk Factors in Sustainable Development of AP Vojvodina" (Project Number 142-451-3554/2017-01/02) that was financially supported by the Provincial Secretariat for Higher Education and Scientific Research.

\section{References}

Ali, R., \& Afzal, M. (2012). Impact of global financial crisis on stock markets: Evidence from Pakistan and India. Journal of Business Management and Economics, 3 (7), 275-282.

Andreou, E., Matsi, M., \& Savvides, A. (2013). Stock and foreign exchange market linkages in emerging economies. Journal of International Financial Markets, Institutions and Money, 27, 248-268. 
Brooks, C. (2008), Introductory Econometrics for Finance - second edition. Cambridge, England, UK: Cambridge University Press.

Cakan, E., Doytch, N., \& Upadhyaya, K.P. (2015). Does US macroeconomic news make emerging financial markets riskier?. Borsa Istanbul Review, 15 (1), 37-43.

Caporale, G.M., Spagnolo, F., \& Spagnolo, N. (2016). Macro news and stock returns in the Euro area: A VAR-GARCH-in-mean analysis. International Review of Financial Analysis, 45, 180-188.

Dedi, L., \& Yavas, B.F. (2016). Return and volatility spillovers in equity markets: An investigation using various GARCH methodologies. Cogent Economics \& Finance, 4 (1), 1266788.

Duppati, G., Hou, Y.G., \& Scrimgeour, F. (2017). The dynamics of price discovery for cross-listed stocks evidence from US and Chinese markets. Cogent Economics \& Finance, 5 (1), 1389675.

Geetha, C., Mohidin, R., Chandran, V.V., \& Chong, V. (2011). The relationship between inflation and stock market: Evidence from Malaysia, United States and China. International journal of economics and management sciences, 1 (2), 1-16.

Gujarati, D. (2010), Basic Econometrics, Fourth Edition. US: The McGraw-Hill Companies.

Kim, H.Y., \& Won, C.H. (2018). Forecasting the volatility of stock price index: A hybrid model integrating LSTM with multiple GARCH-type models. Expert Systems with Applications, 103, 25-37.

Li, T., Zhong, J., \& Huang, Z. (2020). Potential dependence of financial cycles between emerging and developed countries: Based on ARIMA-GARCH Copula model. Emerging Markets Finance and Trade, 56 (6), 1237-1250.

Prasad, N., Grant, A., \& Kim, S.J. (2018). Time varying volatility indices and their determinants: Evidence from developed and emerging stock markets. International Review of Financial Analysis, 60, 115-126.

Rejeb, A.B., \& Arfaoui, M. (2016). Financial market interdependencies: A quantile regression analysis of volatility spillover. Research in International Business and Finance, 36, 140-157.

Shaikh, I., \& Padhi, P. (2013). The information content of macroeconomic news. Procedia Economics and Finance, 5, 686-695.

Zukarnain Z., Sofian S. (2012). "Empirical Evidence on the Relationship between Stock Market Volatility and Macroeconomics Volatility in Malaysia". Journal of Business Studies Quarterly, 4 (2), 61-71.

\section{Internet and other sources:}

EViews8User'sGuideII, 2013, http://www.eviews.com/EViews8/EViews8/E Views\%208\%20Users\%20Guide\%20II.pdf [accessed 29.03.2018.].

European Central Bank, https:/www.ecb.europa.eu/ [accessed 24.04.2018.].

The Federal Reserve System, http://www.federalreserve.gov/ [accessed 24.04.2018.].

Zagreb Stock Exchange, 2016. http://www.zse.hr/ [accessed 13.03.2018.].

Investor Bulletin, Interest rate risk - When Interest rates Go up, Prices of Fixed-rate. [accessed 29.03.2018.].

Belgrade Stock Exchange, 2017. http://www.belex.rs/ [accessed 13.03.2018.].

Central Bank of Croatia, https://www.hnb.hr/ [accessed 15.04.2018.].

Central Bank of Serbia, http://www.nbs.rs/ [accessed 15.04.2018.].

Dow Jones Industrial Average, https://finance.yahoo.com/quote/\%5EDJI/com ponents/?guccounter $=1 \quad$ [accessed 13.03.2018.]. 